\title{
DIAMONDS FROM THE MACAÚBAS RIVER BASIN (MG, BRAZIL): CHARACTERISTICS AND POSSIBLE SOURCE
}

\author{
JOACHIM KARFUNKEL ${ }^{1}$, MAXIMILIANO DE SOUZA MARTINS ${ }^{1}$, RICARDO SCHOLZ ${ }^{1}$ AND TOM \\ MCCANDLESS
}

\begin{abstract}
Physical characteristics of diamonds from the Macaúbas River Basin are described based on a ten point scheme. They have been statistically treated and combined with results of heavy mineral analyses in stream concentrates, as well as with features of ancient and modern sediments. Preliminary results point towards an extra-basinal host igneous rock area lying in the north-northwest. These igneous rocks underwent erosion and the diamonds suffered a gentle fluvial transport. During the Proterozoic São Francisco Glaciation the diamonds were redistributed and deposited in glacial sediments in the proto-Macaúbas River Basin area. Recent fluvial processes eroded these diamonds from the diamondiferous tillites into stream sediments.
\end{abstract}

Keywords: Diamonds Characteristcs, Macaúbas Basin, Glaciogenic Rocks

INTRODUCTION The Macaúbas River, a northwest tributary of the Jequitinhonha River, is located in central-north Minas Gerais State (MG), Approximately $400 \mathrm{~km}$ north of the State's capital Belo Horizonte (Fig. 1). The area of $1000 \mathrm{~km}^{2}$ is relatively unpopulated with only a few and hard to access dirt roads. Although diamonds have been washed in this region for over 200 years, the first scientific study is attributed to Moraes (1932), who introduced the stratigraphic term "formação Macahubas" for a conglomeratic sequence of glacial origin. Hettich (1977) and Karfunkel \& Karfunkel (1977) carried out the first detailed stratigraphic subdivision and proved definitively a glacial origin for the central diamictitic unit of this Group of Proterozoic age.

Karfunkel et al. (1984) and Karfunkel \& Hoppe (1988) elaborated a model which advocated for a continental glaciation about I Ga ago, during which the São Francisco Craton was covered by ice that left its trace in eastern, western, and southern lying fold belts. This event of cold climate has been dated by Pedrosa-Soares et al. (2000) between 950-850 $\mathrm{Ma}$ and has been named by Karfunkel et al. (2000) the São Francisco Glaciation.

Although some authors (e.g. Fleischer 1995, 1998, Almeida-Abreu 1996) postulate the occurrence of diamondiferous pipes in the Espinhaço Range (MG) primary diamondiferous rocks are to date, not known from this region (Karfunkel et al. 1994). The oldest mineralized secondary rocks are diamondiferous metaconglomerates belonging to the Mesoproterozoic Sopa-Brumadinho Formation $( \pm 1.7 \mathrm{Ga}$ ) of the Espinhaço Supergroup. Gonzaga \& Tompkins (1991) describe a glacial transport with fluvial reconcentration of diamonds during later events. An upheaval of the Canastra Arch (Haralyi \& Hasui 1983) and the Espinhaço Range (Karfunkel \& Chaves 1995) during early Cretaceous time gave rise to the formation of the Proto São Francisco and Jequitinhonha rivers, and diamonds have been reworked from these older sequences into both river systems (e.g. Campos et al. 1993, Karfunkel \& Chaves 1995, Chaves \& Karfunkel 1997). The youngest redistribution of

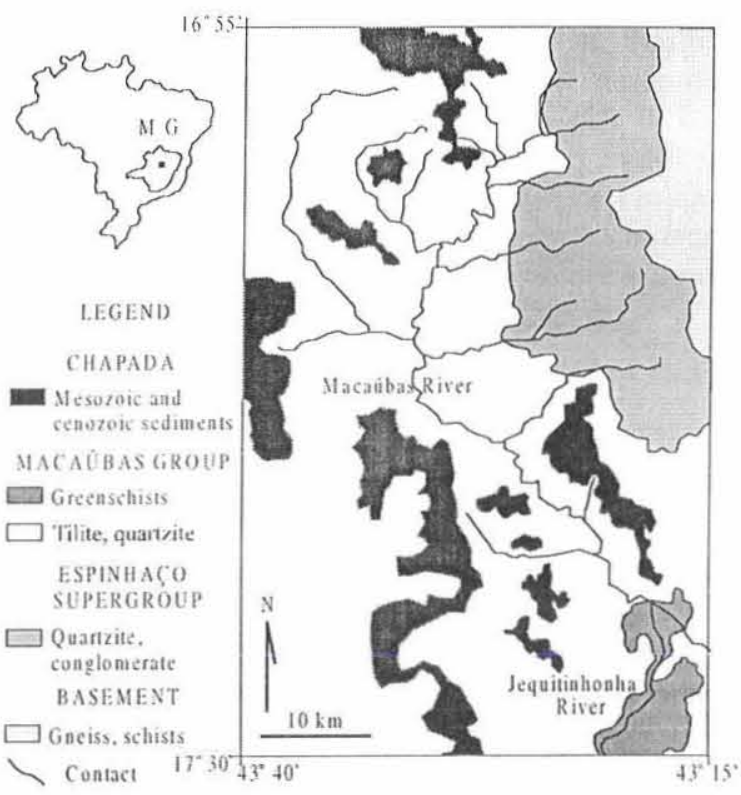

Figure I - Map of the Macaúbas River Basin with its local geology. 
diamonds occurred during Plio-Pleistocene and Holocene time, and recent drainage systems are today the most important sources of diamonds in the Espinhaço Range.

Although diamond exploration in the Macaúbas River Basin in terraces and recent river gravel is similar to other occurrences of the Espinhaço Range, there is a key difference: the Macaúbas Basin and the northern lying, smaller Congonhas Basin are the only places in the State, in which carbonados in notable quantities occur together with diamonds. These and the lack of detailed studies led Martins et al. (2000) to map this area and to study the diamond occurrence.

About $85 \%$ of the Macaúbas River Basin is composed of glaciogenic metasediments of the Macaúbas Group (Fig. 1). Quartzites and locally non-diamondiferous metaconglomerates of the Espinhaço Supergroup comprise the remainder. Remnants of Cretaceous conglomerates have been described by Martins et al. (2000).

The present paper provides a contribution to diamond characteristics of the Macaúbas River Basin. Preliminary statistics of these characteristics are combined with sedimentological features of the Proterozoic glacial and Recent sediments to elucidate possible sources for diamonds from the Macaúbas River Basin.

METHODS To examine diamonds from the Macaúbas River Basin is a difficult task. Today, only a few diggers wash diamonds in these remote areas, accessible only by foot. Therefore the majority of diamonds has been examined in locus, using portable equipment. Diamond descriptions were conducted using a 10X triplet hand lens (for gemological graduation), as well as a zoom binocular loupe (10-60 X magnification) and a hand scale. The description scheme is outlined in Tab. 1, and is based on the schemes devised by other authors (e.g. Robinson 1979, McCallum et al. 1994, McCandless et al. 1994, Otter et al. 1994), with some modifications.

Diamond size has not been grouped according to sieve clas- ses (e.g. Robinson et al. 1989), but adapted to local commercial aspects of diamond dealers in the region. Therefore the measured weight has been divided into six groups $(1=<0.05 \mathrm{ct}$; $2=0.05-0.10 \mathrm{ct} ; 3=0.11-0.15 \mathrm{ct} ; 4=0.16-0.20 \mathrm{ct} ; 5=0.21-0.30$ $\mathrm{ct} ; 6=>0.31 \mathrm{ct})$.

We introduced a simplified gemological grading of stones in the scheme due to the importance in obtaining an idea of rough diamond value (estimated US\$/ct). The color determination is according to the GIA for cut stones (Gemological Institute of America), and for simplicity, grouped into five categories ( $\mathrm{I}=\mathrm{D}$ to $\mathrm{H} ; 2=\mathrm{I}$ to $\mathrm{L} ; 3=\mathrm{M}$ to $\mathrm{P} ; 4=\mathrm{Q}$ or lower; $5=$ fancies), plus the stone's hue (if any) and its intensity. For the clarity classification we used CIBJO (Confédération Internationale de Ia Bijouterie, Joaillerie, Orfèvrerie, des diamants, Perles et Pierres) regulations, because of a certain degree of confusion in interpreting $\mathrm{Pl}$ stones, if written $\mathrm{Il}$ or 11 (according to GIA). Determination has been made with the hand lens (for very small stones the binocular loupe has been used), and classification, for simplicity and local commercial aspects, has been grouped into five categories ( $1=\mathrm{IF}$ to $\mathrm{Vs} ; 2=\mathrm{Si}$ to $\mathrm{Pl}$; $3=\mathrm{P} 2 ; 4=\mathrm{P} 3 ; 5=$ industry).

Because of the smaller magnification of the portable binocular loupe and the type of light source compared with the equipment of the above-mentioned authors, small mineral inclusions could not be identified or even described with sufficient accuracy.

Physical characteristics and gemological grading (slightly modified) of 253 diamonds were determined from May 2000 through June 2001. Due to their dramatically different characteristics, carbonados will be discussed in a forthcoming paper. In addition, $4 \mathrm{I}$ stones have been acquired for more detailed analyses (e.g. scanning electron microscopy). Therefore statistics discussed later in this paper should be considered as preliminary.

DIAMOND CHARACTERISTICS Weight More than half of the examined stones $(57 \%)$ are small diamonds

Table I - Classification scheme for the diamond characteristics of the Macaubas River Basin.

\begin{tabular}{|l|l|l|}
\hline I. ID $+\mathrm{cl}$ & 5. Radiation Spots & 8. X-Regularity \\
\hline 2. Gem. Quality & $\begin{array}{l}\text { 6. Inclusions } \\
\text { 3. Appearance }\end{array}$ & $\begin{array}{l}\text { 7. Morphology } \\
\text { a. Primary b. Secondary }\end{array}$ \\
\hline 4. Coal & & $\begin{array}{c}\text { 10. Surface Features } \\
\text { a. Primary b. Secondary } \\
\text { [Additional comments] }\end{array}$ \\
\hline
\end{tabular}

\footnotetext{
Explanation and/or [e.g.]:

1. [JMP-011 $0.21 \mathrm{ct}$. 2. a. Color + hue + intensity (Pale. Medium. Dark) [J + brownish Pale]: b. Clarity [PI]. 3. Shiny or

Frosty. 4. Coating color + Intensity [Green + Pale|. 5. Radiation Spots Color [brown]. shape (round, square.

rectangle. irregular. others), size (examined with the binocular loupe at $30 \mathrm{X}$ magnification relative to each host crystal size. similar to the relative gemological graduation of the clarity. Large. Medium. Small), and density (a relative term to describe the space distribution of several or many Radiation Spots. Dense. Medium, Searce. others with description). 6. Description of the inclusions.

7. General comments (if any) a. - Single X-Forms (Octahedron, Cube. Transition)

- Twinned (M acle)

- Others

b. Modified from Otter el al. (1994) by joining category 6 and 5

$\begin{array}{llll}\text { Resorp. Cat. } \$ \text { Preserv. } & \text { R.C. } \% \text { Pre. } & \text { R.C. } \% \text { Pre } & \text { R.C. \%Pre }\end{array}$ $\begin{array}{lllll}590-100 & 480-89 & 370-79 & 250-69 & 1<50\end{array}$

8. Nearly Equidimensional. Intermediate. distorted (in all three categories only if $>50 \%$ of the crystal is preserved), not identified.

9. Whole, broken (including cleavage). not identified.

10. General comments (if any)

a. magmatic (e.g. Etch Features, Hillocks. Primary Cleavage, Inclusion Pits, Lamination Lines)

b. sedimentary (e.g. Wear on Apex, Percussion Marks. Secondary Cleavage);

[Additional comments] - [Several large Gletzes reaching diamond surface] or [wear on edges are dubious. Needs SEM].
} 
weighing less than $0.10 \mathrm{ct}$ (Fig. 2), a class referred to by diggers and local dealers as "Fazenda Fina". This dominance of small diamonds could be, in part, the consequence of working previously washed gravel, where most larger stones have already been exploited. Diggers report isolated findings of larger stones years ago, the largest being seven carats and recovered in 1993. The smallest recovered diamond in the present study weigh $0.019 \mathrm{ct}$.

Gem Quality Geological evaluations of secondary diamond deposits and of sedimentological processes are based on gemological grading of stones (e.g. relation between gem and industry diamonds, medium quality of population in diamond deposits), which implies in a commercial point of view. Small diamond of excellent quality are geologically "interesting", but are of no commercial value for the gem market (e.g. the smallest cut brilliant has a weight of $0.000102 \mathrm{ct}$, Malzahn, 2000). Statistics concerning "gemological features" of deposits are therefore to some degree imperfect, and should take into consideration all sizes of diamonds recovered in a deposit.

Changes in the division between gem and industrial stones has been suggested by Levinson (1992) to be called cuttable and industrial, to take in account market oscillations. However, again it limits the possibility of carrying out reliable geological studies that include stones $<0.01 \mathrm{ct}$ in weight.

For this study, we suggest a division in gem-like and industrial-like diamonds. This scheme implies in an evaluation of quality, regardless of commercial point of views (e.g. their size). In this way also very small diamonds or microdiamonds (< I mm according to McCandless et al. 1994) can be incorporated into the statistics.

In a gemological context our suggested classification is a contradiction to existing rules, because grading of cut stones has to be carried out with a daylight-type illumination and a triplet hand lens $10 \mathrm{X}$ magnification. Under such conditions small and microdiamonds cannot be graded. For geological field assessment, however, it is useful to use a less restricted scheme for rough, joining several color and clarity categories

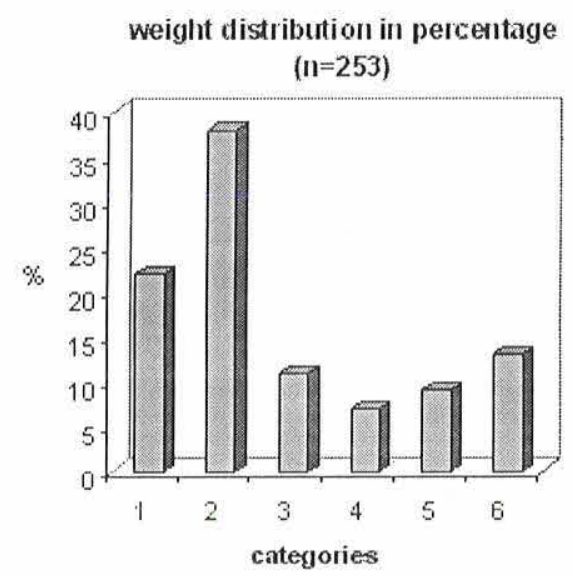

Figure 2 - Weight distribution expressed as percent of total diamonds examined $(N=253)$. in one and the same group, and using even a binocular loupe. In this way the classification of very small diamonds (and even microdiamonds) has the connotation "They look like gem diamonds. If they would have been larger they could be classified (probably) as gem diamonds". Thus we divided the Macaúbas diamonds into 'gem-like' and 'industrial-like' diamonds.

As shown in Fig. 3, 72.6\% of the diamonds belong to Group 1 and 2 Colors, and $71.9 \%$ to Group I Clarity. Only two stones have been classified as fancies (brown). This reflect, preliminary, the quality of Macaúbas diamonds, being medium and lower Colors with a good Clarity.

Appearance Frosting have been classified by McCallum et al. (1994) as coarse, medium, fine, and very fine, and have been explained as late stage magmatic features, not restricted to any particular surface. In a similar way Meyer et al. (1997) describe a frosted surface which resulted not from abrasion, but more likely is the result of gas etching.

Due to our limited equipment we did not divide the diamonds into the above mentioned classes, but observed a variety of coarse, medium and fine frosting. Almost one fifth

\section{Relation between gem-like and industry-like $(n=253)$}

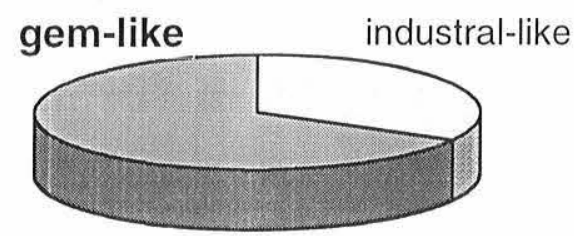

\section{Color and Clarity categories in percentages (gem-like)}

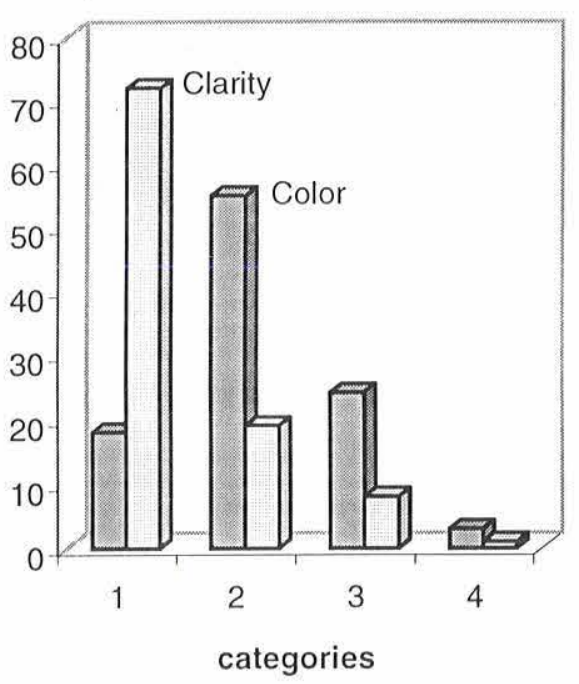

Figure 3 - Relation between gem-like and industry-like diamonds and color/clarity categories of Gem-like diamonds in percentage. 
(18.8\%) of all examined stones show frosting (e.g. Fig. 8 A, E), which is, to some degree, of commercial importance for diggers and local dealers.

Coat In the Espinhaço Range $25 \%$ of diamonds have a green coat, which can be locally as high as $90 \%$ (Chaves et al. 1996). In this category the surface coat color (not the body color), as well as the mottled diamonds have been included. Color and intensity of the coat is due to radiation damage in situ (e.g. Vance et al. 1973) or resulting from the presence of minor elements in this coat (e.g. Orlov 1977). Chaves et al. (this volume) discuss these two hypotheses for Espinhaço diamonds.

We separated diamonds with a thin homogeneous surface color from those of surface mottled stones. Only two of the 253 examined diamonds showed a homogeneous medium green coating, an extremely low number compared to reports of other localities in the Espinhaço Range.

Radiation Spots Radiation Spots, similar to homogeneous surface colored diamonds, are the result of irradiating environments (radioactive minerals and/or radioactive solutions). A total of $56.6 \%$ of all examined diamonds (Fig. 4) show radiation spots. The spots usually have a round or oval shape, but square and rectangular patches have also been observed. They can be described as dense, medium or sparsely isolated spots regarding their arrangement and size.

Spots show in their central part higher color intensities relative to their circumstance area (see also Banko 1997). Some intense green spots give the impression of black spots. This could be the reason for the high percentage of black spots in the statistics, but actually black (?), intense green, and green spots total 77.6\%, which is in agreement with Banko (1997) and Chaves (1997).

Spots of different colors can occur on the same crystal. In some diamonds, rectangular, dark-green patches occur in juxtaposition with brownish to yellow spots with identical shape. This is the consequence of long contact with a radioactive mineral (e.g. monazite, xenotime) resulting in the dark green color, then repositioning of the radioactive mineral relative to the diamond, resulting in a new radiation spot of identical shape. Vance et al. (1973) describe a similar type of damage on diamonds, attributing it to a-particle irradiation. Heating about $600^{\circ} \mathrm{C}$ has also been suggested to be able to change the original green color to brown (Vance et al. 1973). However, detrital diamonds from the $2.5 \mathrm{Ga}$ Witwatersrand

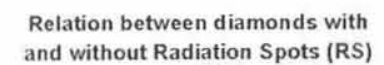

and without Radiation Spots (RS) ( $n=253$ )

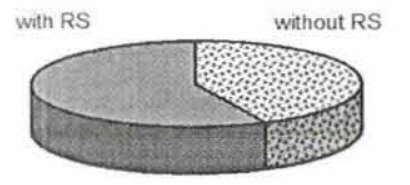

Figure 4 - Relation between diamonds with and without radiation spots and percent of color of these spots. exhibit both green and brown spots, though the diamonds have all been exposed to greenshist facies metamorphism. The spots are actually graphite, which forms upon conversion of the mechanical energy of the a-particle to thermal energy. The green or brown color of radiation spots is purely a consequence of the duration of a-particle damage and the initial concentration of the U-bearing mineral (McCandless, unpublished data). This suggests that the irradiation is from minerals with high $U$ contents, such as from detrital heavy minerals in the sedimentary environment (monazite has been identified by $\mathrm{x}$-ray diffraction). Movement of the radiogenic mineral relative to the diamond results in new spots being formed. The patterns suggest that some of the Macaúbas diamonds were in a secondary deposit for an extended period of time, before being eroded into Recent river systems.

The round to oval spots are difficult to reconcile with diamond in contact with crystalline radioactive minerals. It has been established by studies elsewhere, that these features are likely to be produced by radiogenic fluids in contact with diamonds. The radiogenic fluids result from the decomposition of U-bearing heavy minerals that concentrate with the diamonds in secondary environments, again supporting the deposition of some Macaúbas diamonds in secondary deposits of old geologic age (McCandless, unpublished data).

Inclusions Only in very few diamonds, mineral inclusions such as garnet and olivine could be identified visually (Banko, personal communication). In gemological terms gletzes (fractures) are inclusions too. About one fifth of the examined stones show one to several gletzes. Some reach diamond surface (of primary or secondary origin?), whereas others are internal and interpreted as possible tension cracks reflecting primary magmatic conditions.

Morphology Pristine unresorbed macrodiamonds are rare in nature (Robinson 1979), whereas preserved xenocryst microdiamonds are more abundant in some sampled primary igneous rocks. McCandless et al. (1994) showed a model to explain the degree of preservation of these microdiamonds in a resorbing magma, by protection in xenolith material.

In the stones $16.2 \%$ have been classified as "not identified". No Cube or unresorbed octahedra with perfect plane faces were observed. Octahedra with some degree of modification by tetrahexahedroid rounding (according to the terminology of Robinson et al. 1989), which have been called octahedroid by Orlov (1977), make up less than one fifth of our examined single crystal forms. Only $3.8 \%$ are twinned, being contact twins which are called by diggers "Chapéu de Padre". The remainder majority of stones are classified as transitions (octahedron to Tetrahexahedroid) and Tetrahexahedroid.

As to the secondary morphology, Tab. 2 shows the percent distribution in the five resorption categories (e.g. Fig. 7 C, E and $\mathrm{G})$.

Two of the examined diamonds show uneven resorption, which results, according to Robinson et al. (1989), from partial protection during resorption within a xenolith.

X-Regularity The Macaúbas diamonds have been grouped in four categories as shown in Table 3 (e.g. Fig. $6 \mathrm{~A}, \mathrm{C}, 8 \mathrm{E}$ ). Distortion is a function of a non-uniform development of faces during crystallization and is not related to deformation (Otter et al. 1994). Some examined diamonds show an 
"aerodynamic" or "dogtooth" shape (according to Meyer et al. 1997) and have been classified as "not identified".

X-State Half of the analyzed diamonds (50.4\%) have been classified as broken (mostly cleaved). Based on the sequence of magmatic events (e.g. Robinson et al. 1989, McCandless et al. 1994), we classified the nature of cleavages as primary (magmatic exhibiting etch features, e.g. Fig. $5 \mathrm{~A}, \mathrm{~B}$ ) or of secondary origin (sedimentary, e.g. Fig. 5 C, D, E, F). $77.8 \%$ of the cleaved stones show etch features on their cleaved plane(s) and proved to be of primary (magmatic) origin. About

Table 2 - Secondary morphology due to resorption of the examined diamonds (the 16.2\% of total examined stones and classified as "not identified" are not included).

\begin{tabular}{|c|c|}
\hline $\begin{array}{c}\text { Resorption } \\
\text { Category }\end{array}$ & $\begin{array}{r}\text { Percent of } \\
\text { examined } \\
\text { diamonds }\end{array}$ \\
\hline 5 & 18.4 \\
\hline 4 & 14.9 \\
\hline 3 & 12.3 \\
\hline 2 & 21.9 \\
\hline 1 & 32.5 \\
\hline
\end{tabular}

Table 3 - Percent of crystal regularity of examined diamonds.

\begin{tabular}{|c|c|c|c|}
\hline \pm Equidimensional & Intermediate & Distorted & Not identified \\
\hline $30.5 \%$ & $14.6 \%$ & $32.8 \%$ & $22.1 \%$ \\
\hline
\end{tabular}

one fifth of the cleaved stones (18.9\%) have no etch features on the cleaved plane(s), and exhibit larger wear on edges and/or apices (e.g. Fig. 5 E, F, 8 D, F). These cleavage planes could reflect consequences of sedimentary impact. Only $3.3 \%$ of the cleaved diamonds were classified as having cleavage of unknown origin.

Surface features It is difficult to distinguish between primary (magmatic) and secondary (sedimentary) surface features without the use of high resolution equipment (c.g. scanning electron microscope). The terminology used to describe surface features of the examined diamonds is based on Robinson (1979) and Robinson et al. (1989). They refer to the resorbed form as a "tetrahexahedroid" in contrast to the commonly used "rounded dodecahedron" or "dodecahedroid" used by Orlov (1977). According to McCandless (1989) this is important when considering microdiamonds and diamonds from xenoliths in which flat-faced dodecaherda can occur. Xenocrystic surface features are dominant amongst microdiamonds in Arkansas lamproites (McCandless et al. 1994) and result when resorbing volatiles in the host lamproite or kimberlite have restricted access to the diamond, due to adjoining mineralogical phases. They show features such as knob-like asperities, serrate laminae, tetragonal pitting and crescentic steps. On the other hand, among the macrocrystic surface features other aspects predominate (e.g. hillocks, low relief surfaces).

Lamination lines are created according to Urusovskaya \& Orlov (1964) by slippage along glide planes in the diamond due to plastic deformation. They indicate ductile deformation when enclosed in peridotite or eclogite at mantle conditions (McCandless et al. 1994). According to Robinson et al. (1989) graphitization along planes in diamond may account for the correlation between lamination lines and brown color of stones from primary rocks.

The examined diamonds from the Macaúbas River Basin have $42 \%$ with lamination lines (e.g. Fig. 8 A, B). They are usually closely spaced and parallel linear, and are most obvious on tetrahexahedral faces produced by resorption. Few stones show cross-hatched lamination lines associated with shagreen (e.g. Fig. $8 \mathrm{~A}, \mathrm{E}$ ). There is no relation between diamond size and frequency of lamination lines. Although deformation

Table 4 - Surface features of examined diamonds expressed in percentages (several diamonds may exhibit more than one surface features, hence total is greater than 100\%).

\begin{tabular}{|l|c|}
\hline Lam ination Lines & $42 \%$ \\
\hline Low Relief Surface & $64 \%$ \\
\hline Hillocks & $76 \%$ \\
\hline Pitting, Cavities, Ruts, Grooves, & $72 \%$ \\
\hline Hollows & \\
\hline Trigons & $16 \%$ \\
\hline
\end{tabular}

predates resorption there is no evidence for the length of time between processes.

Orlov (1977) suggests that deformation is related to xenolith disaggregation i.e. related to kimberlite eruption. Robinson et al. (1989) advocate that deformation occurs during the same event which forms sheared peridotites. However, diamond has yet to be found in association with such rocks (Otter et al. 1994). According to them it seems possible, that diamond deformation may occur soon after crystallization, possibly due to stresses within the confines of its host rock. McCandless et al. (1994) believe that deformation with graphitization may also be caused by heating associated with stress at the time of conduit formation for the ascending magma.

Robinson et al. (1989) suggested that lamination lines are more commonly developed in brown than in yellow to colorless diamonds. On the other hand, many diamonds with lamination lines are colorless. The stones from the Macaúbas River Basin do not show any correlation between brownish color and lamination lines, which suggest (in agreement with McCandless et al. 1994) that some deformation must have taken place prior to conduit formation.

Dissolution produces another type of surface feature in form of triangular pits (trigons) on the octahedral faces, which are oriented anti-parallel to the face configuration. Such trigons could be identified on 16\% of Macaúbas diamonds (e.g. Fig. 5 A, B). Both types described by Orlov (1977), the pointed 
trigons and the flat-bottomed trigons have been observed on the examined stones. Pointed trigons often develop in groups whereas the flat-bottomed type are isolated and not connected.

Low relief surface features have been observed on $64 \%$ of Macaúbas diamonds. They include shagreen texture (e.g. Robinson 1979) and are represented by abundant small hillocks (e.g. Fig. 8 F), which gives the stones a translucent appearance (McCandless et al. 1994), and represent the advanced stages of resorption. Medium to coarse pyramidal, and less common, blocky hillocks occur on $76 \%$ of examined diamonds. They are more common on advanced tetrahexahedroid forms. According to Orlov (1977) pyramidal hillocks are formed simultaneously with the curved-faced surface, when the round crystal faces show a specific structure, so that their forms depend on the curvature features of the faces and their relative position on the faces. Although the most frequent form is triangular pyramids, blocky hillows (which Orlov called quadrangular pyramids) can develop at edges.

Pitted cavities, grooves, ruts and hollows are observed on $72 \%$ of Macaúbas diamonds. About one quarter of these show well defined large inclusion pits on broken surfaces (e.g. Fig. 8 A, B). Such pits are believed to represent, according to Otter at al. (1994) mineral inclusions that facilitated breakage of the host diamond due to internal strain developed by differential expansion during eruption. Etch channels penetrating deep into the tetrahexahedroidal faces have been observed on several Macaúbas diamonds (e.g. Fig. 7 A, B, G, H). Some extensive half-moon-like "percussion marks" are seen at higher magnification to be etch features on their internal surfaces, which prove that they are not of sedimentary impact origin, but represent igneous etch channels (e.g. Fig. 6 B, D). Corrosion sculpture on tetrahexahedral surfaces which imply, according to Orlov (1977) that corrosion took place only after dissolution, could be observed only on few Macaúbas diamonds.

As to the secondary features of Macaúbas diamonds, $16.2 \%$ exhibit percussion marks as described above e.g. Fig. 6 E, F), a relatively low percentage in comparison with other regions of the Espinhaço Range (e.g. Banko 1997, Chaves 1997). Only $27.2 \%$ of the same population show wear on edges and/or apex (e.g. Fig. 5 F, 8 D, F). Some diamonds are of irregular shape with tale-like extensions. Of the cleaved diamonds $22.2 \%$ show no etch features. The cleavage and wear of these stones have been considered as of secondary sedimentary origin. For the $3.3 \%$ cleaved diamonds without any diagnostic features, SEManalyses are necessary to confirm their cause.

\section{CHARACTERISTICS OF MACAÚBAS BASIN}

SEDIMENTS The northeastern part of the Macaúbas River Basin (about 15\% of the total basin area) is composed of Mesoproterozoic quartzites with locally metaconglomeratic lenses of the Espinhaço Supergroup. According to Karfunkel \& Karfunkel (1977) these conglomeratic lenses, interpreted as shore deposits could represent the source of the, recent diamondiferous gravel of the basin.

Martins et al. (2000) propose that these conglomerates are quite different from the deeply weathered diamondiferous Sopa-conglomerates of the Diamantina region. There is no record of any successful exploiting activities in the Espinhaço conglomerates of the Macaúbas Basin and according to experienced diggers they are barren.

The majority of the rock units in the Macaúbas River Basin are composed of glaciogenic metasediments of early
Neoproterozoic age of the São Francisco Glaciation. Karfunkel \& Karfunkel (1977) recognized three main glacial facies regarding the depositional environment (i) glacial-continental facies (ii) grounded shelf-ice facies, and (iii) glaciomarine facies. The Macaúbas River Basin sediments have been interpreted as grounded shelf-ice deposits. Martins et al. (2000) demonstrated that thickness of these deposits is in the order of 250-350 $\mathrm{m}$ all over the basin area. Many outwash sediments and eskers have been identified (Karfunkel \& Karfunkel 1977), locally with slumping features. Eskers are oriented in several directions, but northwest-southeast directions predominate. This is in agreement with Dupont et al. (2000), and Karfunkel et al. (2000) who claim ice-transport directions in the continental facies from NNW towards SSE.

Glacial sediments of the Macaúbas Basin underwent regional metamorphism at the end of Precambrian and exhibit today low to medium greenshist facies metamorphic overprint.

Diamictites (sensu Pettijohn 1957) have heterogeneous grain-size distribution and can incorporate granule, gravel, cobble, and boulder of all sizes, composition, angularity and sphericity. Diamictites of glacial origin (tillites) show this features in the examined area, and the largest observed boulder in the tillite of the Macaúbas River Basin has a diameter over $1 \mathrm{~m}$. Grain-size distribution analyses from tillites of the Macaúbas River Basin and from recent gravel have been carried out from several localities. Remarkable is a relatively homogeneous grain-size distribution from different basin samples (tillite and recent gravel). This reflects uniform transport conditions and similar source rock(s) for the (glaciogenic and recent) sediments in the area. Granule, pebble, cobble, and boulder counts for $5-10 \%$ of the total sediment load (in agreement with Karfunkel et al. 1984) and are of different composition (e.g. quartzites, quartz, granitoid rocks, carbonates). The clay-silt, the very fine sand, and the fine sand fractions make up together about one fifth of the matrix, whereas about two thirds show grain sizes up to $2 \mathrm{~mm}$. The recent gravel is poor in the clay-silt, the very fine sand, and the fine sand fractions.

Very locally Martins et al. (2000) registered remnant Cretaceous conglomerates. In other regions these conglomerates have been interpreted as formed during upheaval of the Espinhaço Range in early Cretaceous time (e.g. Karfunkel \& Chaves 1995, Chaves \& Karfunkel 1997 ). Precambrian diamondiferous conglomerates have been reworked and distributed to these Phanerozoic sediments. The remnant conglomerates of this epoch in the Macaúbas River Basin are probably not diamondiferous because their Espinhaço source rocks lying in the east, as showed by Martins et al. (2000) are barren. Thus the ultimate primary source of the Macaúbas diamonds remains an enigma.

Recent diamondiferous gravel in the Macaúbas River Basin has been analyzed for mineralogical composition. Garnet (almadine-pyrope), staurolite, Chrisoberyl and monazite, identified by X-ray difraction and Micro-Raman-Probe, are exotic and do not occur in the lower/medium greenshist metamorphic facies or other rocks in the Macaúbas River Basin. Yellow-greenish chrisoberyl of gem-like quality up to $0.8 \mathrm{~cm}$ in diameter and monazite are of pegmatitic origin. Pegmatites, have not been identified during detailed mapping of Martins et al. (2000) in the Macaúbas River Basin. Garnet and staurolite occur many dozens of $\mathrm{km}$ to the east of the basin (Costa 1987) and no transport from this region towards the 
Macaúbas River Basin is known. Thus, source rocks of these minerals could have originated towards the northwest. Transport by ice, as postulated by Gonzaga (personal communication) during the São Francisco Glaciation from their original source towards the actual Macaúbas River Basin, in pebbles, cobbles, boulders or even in part of the matrix, is plausible. This is of primary importance for considering the geographic source area of Macaúbas River Basin diamonds.

DISCUSSION Most papers dealing with diamond characteristics and their (secondary) deposits discuss in detail either the geology of deposit(s) or concentrate on description of diamonds. However, both aspects are in general linked and should be discussed equally.

The history of Macaúbas River Basin diamonds in their ancient and recent sedimentary environments is extremely complex and difficult to interpret. Therefore we tried to couple characteristics of diamonds (primary and secondary), identify heavy minerals occurring in diamondiferous gravel, facies analyses, paleogeography and transport direction studies of glacial sediments.

The Macaúbas River Basin show the following peculiarities compared to other diamondiferous areas of the Espinhaço Range in Minas Gerais (i) the majority of its area is composed by glacial sediments of the Macaúbas Group (ii) it is (together with the smaller northern lying Congonhas Basin) the only place in the State in which carbonados occur in notable quantities together with diamonds (iii) diamond characteristics are partly different in contrast to those of other diamondiferous fields, and (iv) occurrence of some exotic heavy minerals, which can not genetically be related to the local geology.

The source of Macaúbas River Basin diamonds is still debatable, but the combination of data allows to establish a preliminary hypothesis for their origin.

Half of the examined diamonds are cleaved, of which three quarters are attributes to primary processes. This is not consistent with the results obtained by other authors (e.g. Karfunkel et al. 1996, Banko 1997, Chaves 1997, Banko \& Karfunkel 2000) for diamonds from the Espinhaço Range in Minas Gerais. These authors postulated that diamonds in the Espinhaço Range underwent natural selection (sensu Sutherland 1982) due to long fluvial transport from a distant source area, evidenced mainly by crystal morphology, crystal state, gem quality and some surface features of secondary origin (Chaves et al. 1998).

On the other hand Haralyi et al. (1991) described a decrease in diamond size along the Jequitinhonha River course associated with sedimentary processes, except when some large tributaries (mainly the Macaúbas River) enter the drainage system. Gonzaga \& Tompkins (1991) attributed this fact to features of the tributary area sediments, which are of glacial origin, thus advocating that the glacial transport of diamonds played an important role in diamond distribution.

According to the experimental studies of McCandless (1990) minerals are transported in a high-energy fluvial system with less wear when the finer-grained proportion of the gravel is increased. The presence of fine-grained material in the gravel can significantly hinder the wear of the minerals, probably because the fine-grained component cushions these minerals from contact with the clasts by increasing the overall viscosity of the sediment charge. McCandless (1990) emphasize that these effects must be considered when attempting to correlate the wear of xenocryst minerals from stream sediments with the proximity of their source.

The homogeneous grain-size distribution of sediments associated with the diamond characteristics in the Macaúbas River Basin is not consistent with the different degrees of wear observed on its diamonds. Therefore a fluvial transport solely can not explain the characteristics of diamonds in the Macaúbas River Basin. Local geological features, exotic minerals in heavy concentrates, as well as characteristics of the examined diamonds point towards a glacial contribution to fluvial processes in the redistribution of diamonds, reinforcing Gonzaga \& Tompkins (1991) model.

CONCLUSIONS Although diamonds from the Espinhaço Range and their (secondary) deposits have been studied for over 100 years, their primary source rock is, up to date, unknown. The many magmatic cleaved diamonds summing up with the other mentioned preserved primary (magmatic) surface features indicate either a proximal kimberlitic/lamproitic source or a different sedimentary transport mechanism than fluvial. The latter hypothesis is reinforced by the presence of exotic minerals in the basin gravel, as well as the absolute predominance of glacial sediments. Thus, an extra-basinal (outside the actual geographic site of the basin) source for the Macaúbas River Basin diamonds transported by ice during Neoproterozoic time is plausible.

The estimated amount of diamonds washed in the last 200 years, the size of the basin, as well as grain-size-distribution in recent and ancient sediments, combined with wear features on diamonds, and the abscent of bort (sensu Gaal 1977) are however not consistent with a direct glacial erosion and transport from kimberlitic/lamproitic rocks. It is much more likely that magmatic sources underwent primary decomposition and erosion. Posterior gentle fluvial processes transported and concentrated diamonds prior to the São Francisco Glaciation. This glaciation was responsible for the removal of the diamonds from their source (secondary and ?primary) by ice and posterior deposition in the (actual) Macaúbas River Basin area. A renewed fluvial transport during recent time concentrated the tillite diamonds to their present sites.

The Gonzaga \& Tompkins (1991) model for a glacial transport and redistribution of diamonds seems to be reasonable. Nevertheless, glacial transport is not responsible for the concentration of diamonds, but only for their geographic dislocation (and to a certain amount dispersion). It is quite clear that later, mainly fluvial processes reworking these glacial diamondiferous sediments have the capacity of concentrating diamonds. It is important to note that the morphology and surface features indicate a unique source for Macaúbas diamonds and that such surface features do not have aspects that are uniquely glaciogenic in nature.

It is still too early to define a geographical area for the primary source rock(s) of the Macaúbas River Basin diamonds. Notwithstanding we can postulate that they have been transported by ice from a north-northwestern lying area.

Acknowledgements To Conselho Nacional de Desenvolvimento Científico e Tecnológico $(\mathrm{CNPq})$ and Fundação de Amparo à Pesquisa de Minas Gerais (FAPEMIG) for financial support and to reviewers of RBG for suggestions to the manuscript. 

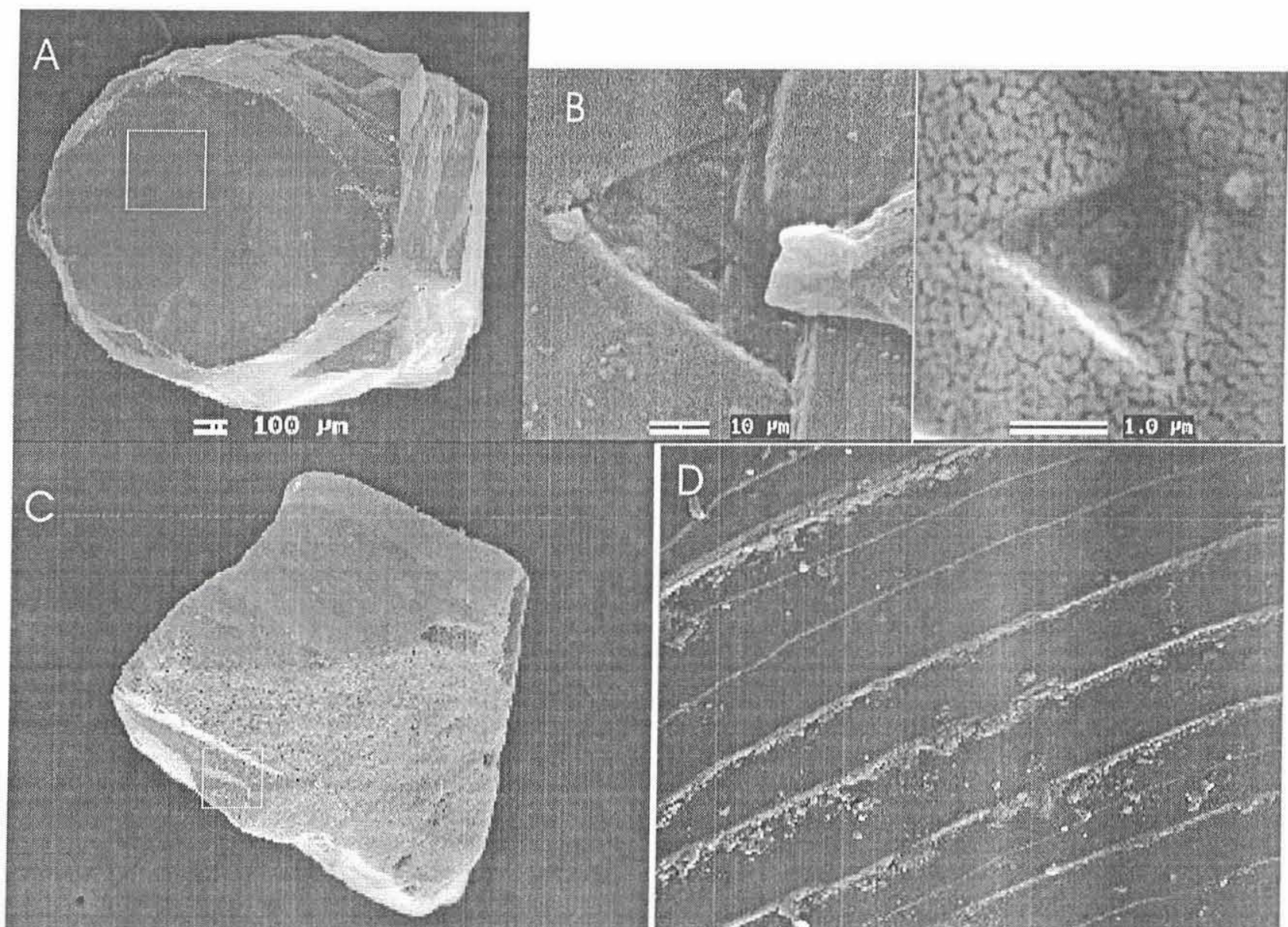

-1. $100 \mathrm{\mu m}$
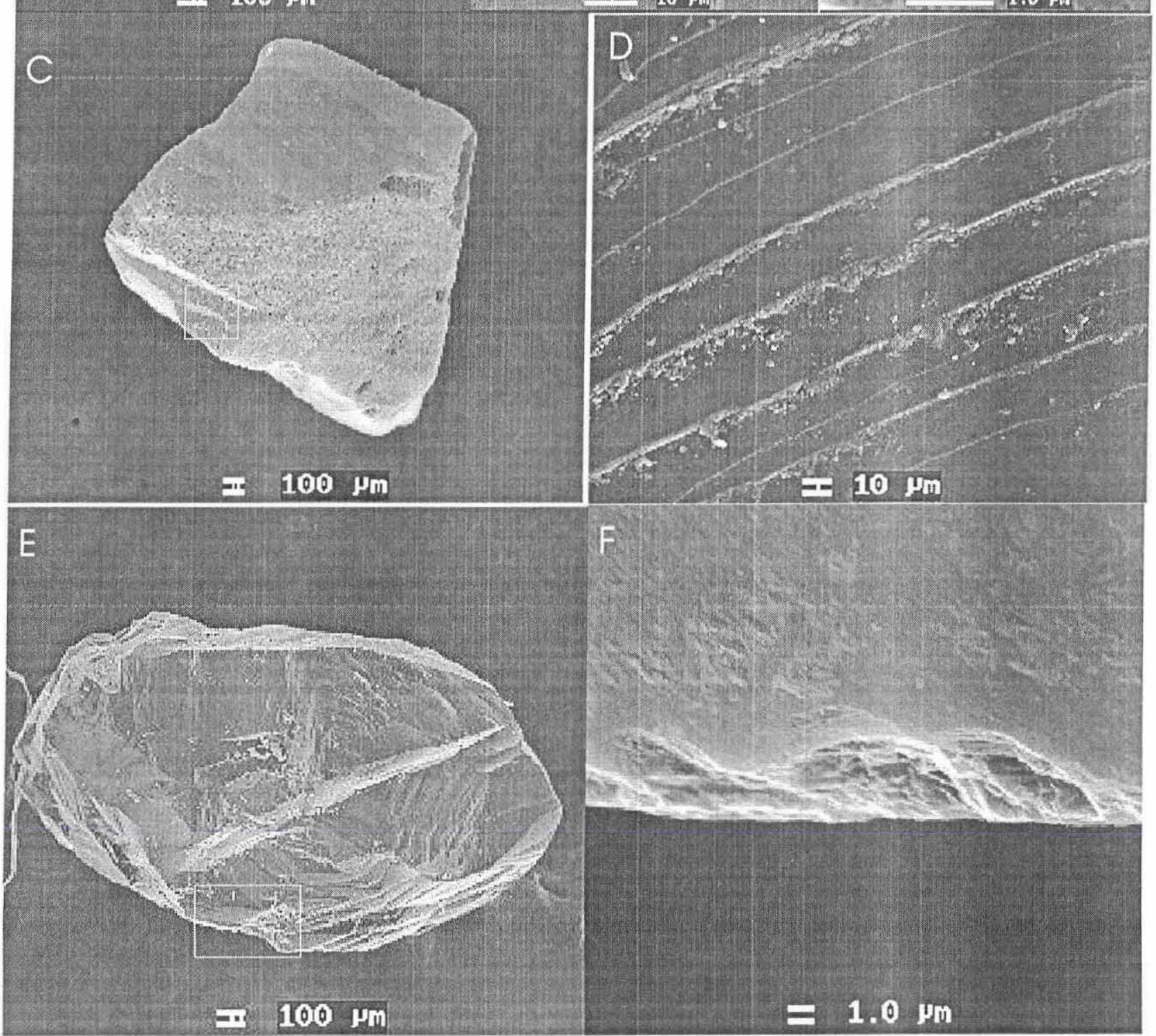

Figure 5 - SEM microphotographs of diamonds with primary (magmatic) and secondary (sedimentary) cleavages. (A) M151-1, primary clevage. $(B)$ detail of " $A$ " showing trigons on cleavage proving that the cleavage is of primary origin. Left - trigon with small other trigons on its bottom, right - detail of the left trigon showing a cracked clay cover: (C) M08-I, fragment with secondary cleavage. $(D)$ detail of " $C$ " showing step-like cleavage with wear proving the secondary origin of the cleavage. (E) M06-I, fragment showing cleavage of secondary origin with wear: $(F)$ detail of " $E$ " showing the wear: 

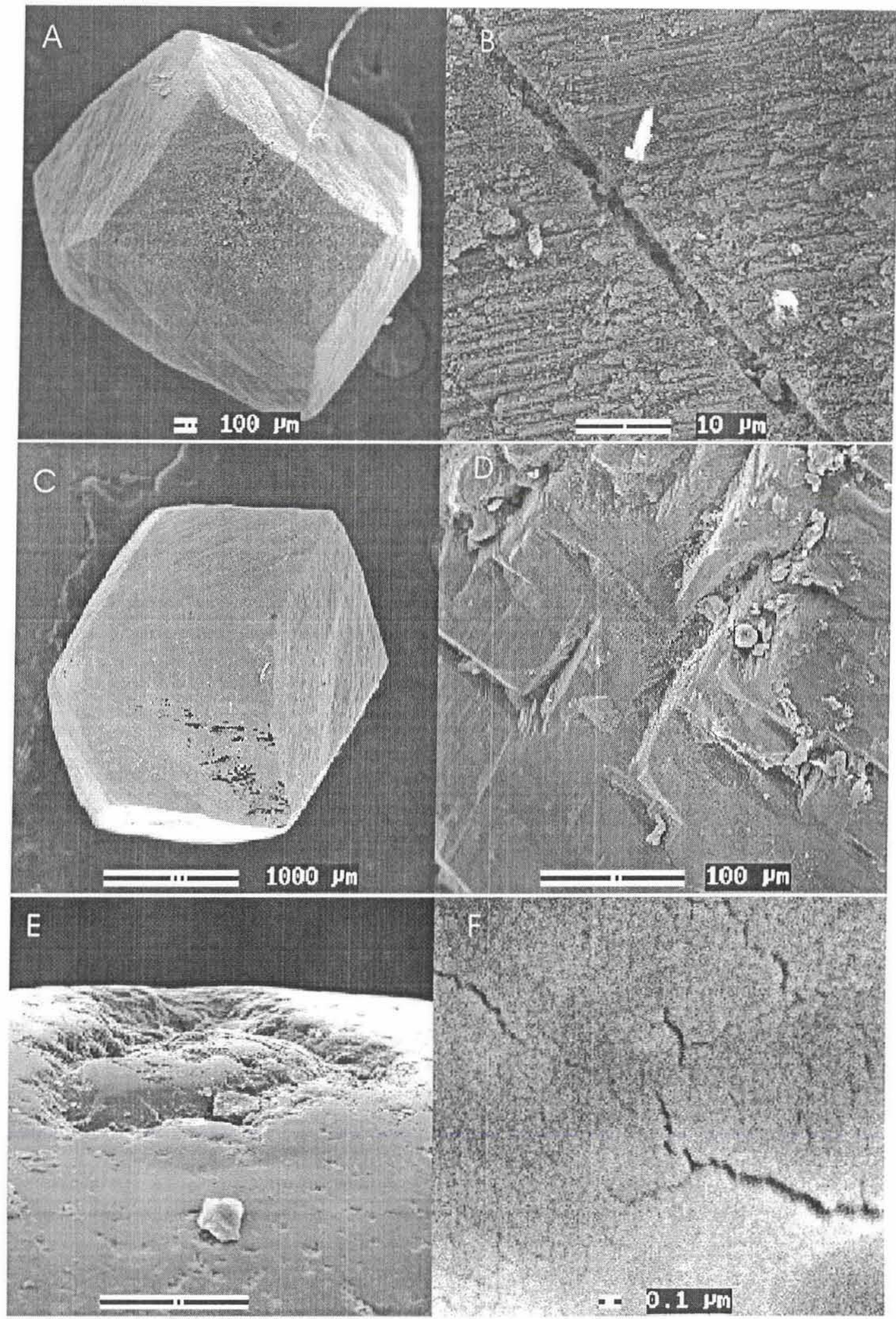

Figure 6 - SEM microphotographs of diamonds with pseudo percussion marks and true percussion marks. (A) M1512-1, tatrahexahedroid crystal with lamination lines, hillocks, sharp edges and hair-like straight or curved "percussion marks". (B) detail of "A" showing that the "percussion marks" are actually deep etch channels. (C) MMG08-I, tetrahexahedroid crystal with percussion marks. $(D)$ detail of " $C$ " reveals that some percussion marks are actually etch channels and not sedimentary features. (E) MZ3I-5, a percussion mark covered with a layer of secondary material, probably clay. $(F)$ detail of "E" showing the cracks in the clayish material. 

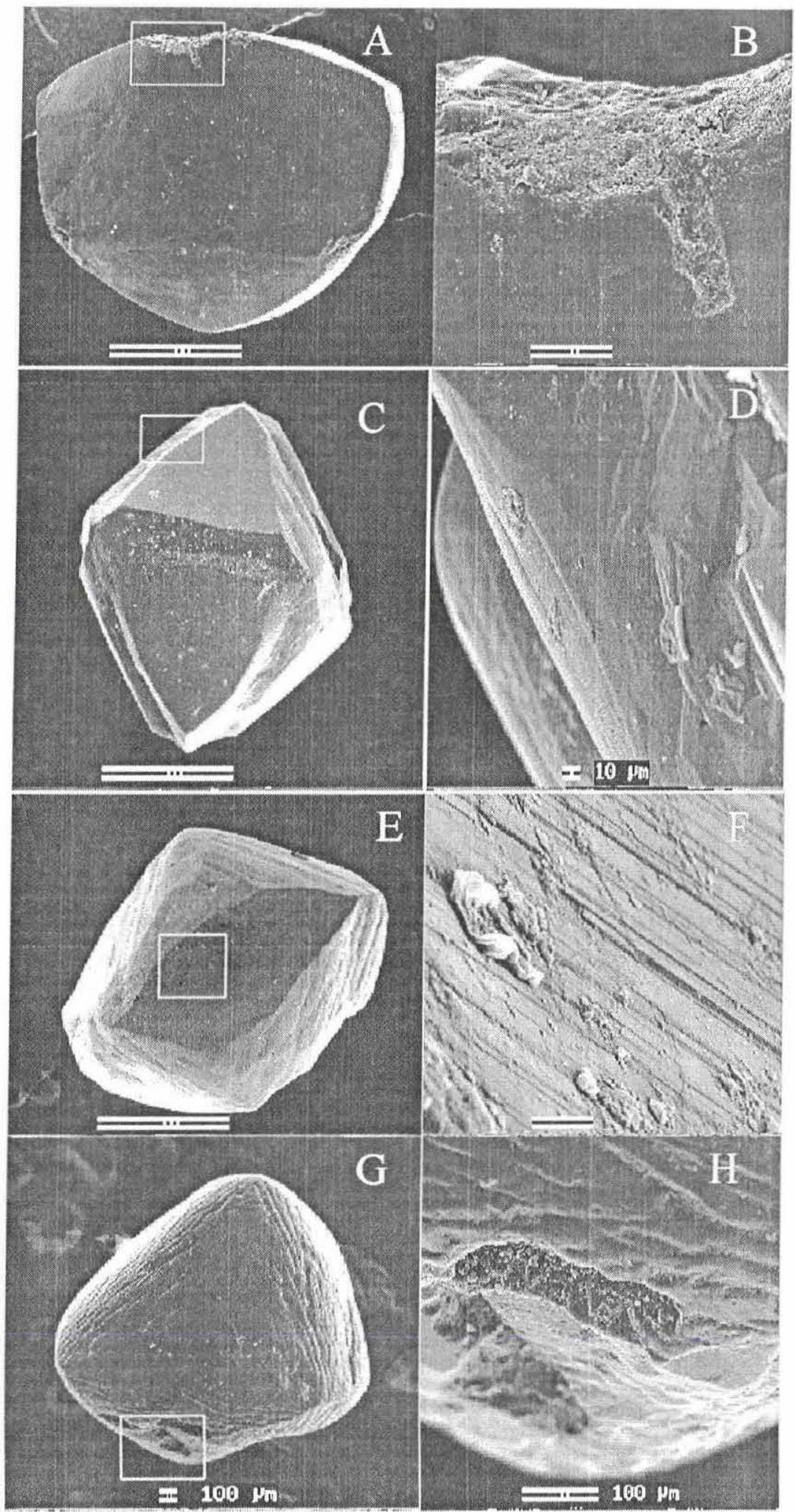

Figure 7 - SEM microphotographs of diamonds with magmatic dissolution and sedimentary wear: (A) MZ3I-I2, flat tetrahexahedroid crystal with "wear" on the upper part. Scale bar is $100 \mathrm{~m}$. (B) detail of "A " reveals that the "wear" is of primary nature due to resorption. Scale bar is $10 \mathrm{~m}$. (C) MZMP2-I, octahedron of resorption category 4 . Scale bar is $1000 \mathrm{~m}$. (D) detail of "C" showing no sign of wear: (E) MGRD-I, tetrahexahedroid of resorption category 2, showing lamination lines and hillocks. Scale bar is $100 \mathrm{~m}$. (F) detail of "E" showing the parallel hillocks. Scale bar is $1 \mathrm{~m} .(G)$ MTIO1-4, transition of resorption category 3 with ruts and incission pits on the liower part. Shield-like hillocks. No sign of wear. (H) detail of "G" showing the etch features of the lower part. 

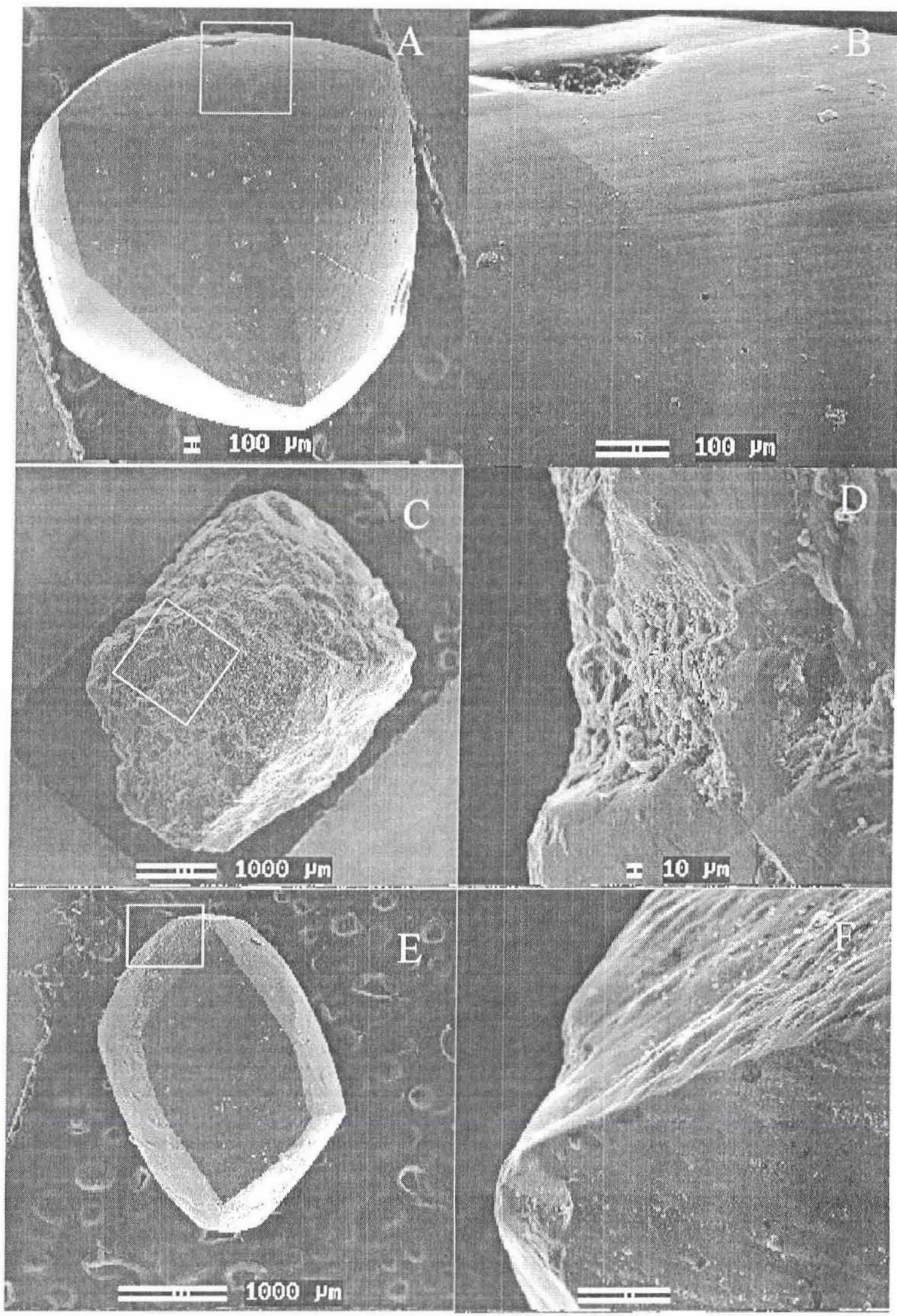

Figure 8 - SEM microphotographs of diamonds with inclusion pits and wear: (A) MBOI-I, flat tetrahexahedroid with an inclusion pit on the upper part and a breakage on the lower right side. Shagreen texture. (B) detail of "A" showing that the inclusion pit is covered with a clay layer; but still showing parallel linear; closely spaced lamination lines. (C) MBO2-I, fragment with some wear: (D) detail of " $C$ " showing the breakage. (E) MXX-l, distorted tetrahexahedroid showing lamination lines, percussion marks and some wear on edges. $(F)$ detail of " $E$ " showing breakage on apex (left side). Scale bar is $10 \mathrm{~m}$. 


\section{References}

Almeida-Abreu P.A. 1996. O caminho das pedras. Geonomos, 4:77-93.

Banko A.G. 1997. FTIR-Spektroskopische Untersuchungen an Beryllen unterschiedlicher Herkunft, sowie die geologische, mineralogische und gemmologische Charakterisierung der Diamanten des Espinhaço-Gebirges (Minas Gerais, Brasilien). PhD thesis, University of Wien/Austria. 186 p.

Banko A.G. \& Karfunkel J. 2000. Die Mineralogie und Gemmologie der Diamanten aus der Serra do Espinhaço, Minas Gerais, Brasilien. Zt. Gemmol. Ges., 49(3): 127-150.

Campos J.E.G., Dardenne M.A., Gonzaga G.M. 1993. O potencial diamantífero do conglomerado Abaeté no NW de Minas Gerais. In: Simp. Brasil. Geol. Diamante. I. Anais...,Cuiabá.UFMT, Publ. Esp., 2:101-113.

Chaves M.L.S.C. 1997. Geologia e mineralogia do diamante da Serra do Espinhaço em Minas Gerais. PhD thesis, University of São Paulo, São Paulo/Brazil. 289 p.

Chaves M.L.S.C. \& Karfunkel J. 1997. A protobacia do Rio Jequitinhonha durante o Cretáceo Inferior e seu potencial diamantífero. Geociências, 16:191203.

Chaves M.L.S.C., Karfunkel J., Banko A.G., Stasiulevicius R., Svisero D.P. 1996 Diamante de capa verde: frequência, distribuição e possível origem nos depósitos diamantíferos de Minas Gerais. Bol. IG-USP, Série Científica, 27:32-4I.

Chaves M.L.S.C., Karfunkel J., Svisero D.P. 1998. Sobre a polêmica da origem do diamante na Serra do Espinhaço (Minas Gerais): um enfoque mineralógico. Rev: Bras. Geociências, 28(3):285-294

Costa A.G. 1987. Petrologie und geochemische Untersuchungen des GneisMigmatit-Gebietes von Itinga, Jequitinhonha-Tal, nordöstliches Minas Gerais, Brasilien. PhD thesis, University of Clausthal/Germany. 287 p.

Dupont H., Espinoza J., Karfunkel J., Noce C.M. 2000. Glacial deposits of the Neoproterozoic Glaciation: the Serra do Cabral and vicinities (Minas Gerais, Brazil). In: Internat. Geol. Congr. 31, Rio de Janeiro. Abstracts (in CD-ROM).

Fleischer R. 1995. Prospeç̧ão e economia do diamante da Serra do Espinhaço. Geonomos, 3(1):27-30.

Fleischer R. (1998): A rift model for the sedimentary diamond deposits of Brazil. Mineral. Deposita, 33:238-354.

Gaal R.A.P. 1977. The diamond dictionary. Santa Monica, Gemological Institut of America. 342 p.

Gonzaga G.M. \& Dardenne .M.A. 1991. The Jequitai glaciation and the dispersion of diamonds during Upper Proterozoic. In: $5^{\text {th }}$ Internat. Kimberlite Conf., Leonardos O.H., Meyer H.O.A., Gaspar J.C. (eds), Field Guide Book, CPRM:89-93.

Gonzaga G.M. \& Tompkins L.A. 1991. Geologia do diamante. In: Principais depósitos minerais do Brasil, C. Schobbenhaus, E.T. Queiroz, C.E.S.Coelho (eds.). DNPM/CPRM, vol.4A:53-116.

Haralyi N.L.E. \& Hasui Y. 1983. The gravimetric information and the ArcheanProterozoic structural framework of Eastern Brazil. Rev. Bras. Geociências, 12:160-166.

Haralyi N.L.E., Hasui Y., Morales N. 1991. O diamante Pré-Cambriano da Serra do Espinhaço, Minas Gerais. In: Principais depósitos minerais do Brasil, C. Schobbenhaus, E.T. Queiroz, C.E.S.Coelho (eds.). DNPM/CPRM, vol.4A:209-222.

Hettich M. 1977. A glaciação proterozóica no centro-norte de Minas Gerais. Rev: Bras. Geociências, 7:87-101.

Karfunkel J. \& Karfunkel B. 1977. Fazielle Entwicklung der mittleren Espinhaço Zone mit besonderer Berücksichtigung des Tillit-Problems (Minas Gerais, Brasilien). Geol. Jb., 24:3-91.

Karfunkel J. \& Chaves M.L.S.C. 1995. Conglomerados Cretácicos da Serra do Cabral, Minas Gerais: Um modelo para a redistribuição coluvio-aluvionar dos diamantes do Médio São Francisco. Geociênciuss, 14:59-72.

Karfunkel J. \& Hoppe A. 1988. Late Proterozoic glaciation in central-eastern Brazil: synthesis and model, Palaeogeogr., Plalaeoclimat., Palaeoecol., $65(2): 1-2 \mid$.

Karfunkel J., Horta Moreira P.C., Ribeiro M.C., Costa Franco A.L. 1984. Aspectos genéticos e deposicionais do Grupo Macaúbas na região da Barragem do Paraúna e sua importancia na contribuição para um modelo paleogeográfico e geotectônico. In: SBG, Congr. Bras. Geol., 33, Rio de Janeiro, Anais, Vol. IV:3091-3103.

Karfunkel J., Chaves M.L.S.C., Svisero D.P., Meyer,H.O.A. 1994. Diamonds from Minas Gerais, Brazil: An update on sources, origin and production. Internat. Geol. Rev.,36:1019-1032.

Karfunkel J., Chaves M.L.S.C., Hoppe A., Banko A.G. 1996. Diamanten des Espinhaço-Gebirges (Minas Gerais, Brasilien): Gemmologische und ökonomische Folgen geologischer Geschichte. Zt. Dt. Gemmol. Gess. 45(3): $113-125$.

Karfunkel J., Dupont H., Hoppe A., Schobbenhaus C., Noce C.M., Peregovich B. 2000. The Neoproterozoin São Francisco Glaciation in Central-Easterı Brazil. Profil, Bd., 19 (in CD-ROM).

Levinson A.A., Gurney J.J., Kirkley M.B. 1992. Diamond sources and production: past, present, and future. Gems \& Gemology, 28(4):234-254

Malzahn H. 2000. Diamant, der extreme Edelstein, das geniale Werkzeug ExtraLapis, 18: 68-75

Martins M., Karfunkel J., Addad J., Scholz R., Peregovich B. 2000. Das Macaúbas-Becken in zentral-nord Minas Gerais, Brasilien und seine Diamantvorkommen. Profil, Bd., 19 (in CD-ROM).

McCallum M.E., Huntley P.M., Falk R.W., Otter M.L. 1994. Morphological resorption and etch feature trends of diamonds from kimberlite population within the Colorado-Wyoming State Line District, USA. In: Internat. Kimberlite Conf., 5, Araxá, 1991, Proceedings...Araxá, CPRM, Brasilia, vol. 2: diamonds: characterization, genesis, and exploration: 32-50.

McCandless T.E. 1990. Kimberlite xenocryst wear in high-energy fluvial systems: experimental studies. Journ. Geochem. Expl., 37:323-331.

McCandless T.E., Waldman M.A., Gurney J.J. 1994. Macrodiamonds and microdiamonds from Murfreesboro Lamproites, Arkansas: morphology, mineral inclusions and carbon isotope geochemistry. In: Internat. Kimberlite Conf., 5, Araxá, 1991, Proceedings...Araxá, CPRM, Brasilia, vol. 2: diamonds: characterization, genesis, and exploration: 78-97.

Meyer H.O.A., Milledge H.J., Sutherland F.L., Kennewell P. 1997. Unusual diamonds and unique inclusions from New South Wales, Australia. Russium Geol. And Geophysics, 38(2):305-331.

Moraes L.J. 1932. Área occupada pela formação Macahubas no norte de Minas Gerais. Acad. Bras. Ciências, 4:111-114.

Orlov Y.L. 1977. The mineralogy of the diamond. John Wiley \& Sons, New York, $235 \mathrm{p}$.

Otter M.L., McCallum M.E., Gurney J.J. 1994. A physical characterization of the Sloan (Colorado) diamonds using a compreensive diamond description scheme. In: Internat. Kimberlite Conf., 5, Araxá, 1991, Proceedings...Araxá, CPRM, Brasilia, vol. 2: diamonds: characterization, genesis, and exploration: 15-31.

Pedrosa-Soares A.C., Cordani U.G., Nutman A. 2000. Constraining the age of Neoproterozoic glaciation in eastern Brazil: first U-Pb (SHRIMP) data of detrital zircons. Rev. Bras. Geociências, 30: 58-61.

Pettijohn F.J. (1957): Sedimentary rocks. Harper \& Broth., New York, 718 p.

Robinson D.N. 1979. Surface textures and other featuresd of diamonds. Ph.D. thesis, University of Cape Town/South Africa. 221 p.

Robinson D.E., Scott J.A., Van Niekerk A., Anderson V.G. 1989. The sequence of events reflected in the diamonds of some southern African kimberlites. Geol. Soc. Australia, Sp. Publ., 14(2):990-1000.

Sutherland ,D.G. 1982. Tyhe transport and sorting of diamonds by fluvial and marine processes. Econ. Geol., 77(7):1613-1620.

Vance E.R., Harris J.W., Milledge H.J. 1973. Possible origins of a-damage in diamonds from kimberlite and alluvial sources. Mineral. Mag., 39:349. 360 .

Urusovskaya A.A. \& Orlov Y.L. 1964. Nature of plastic deformation of diamond crystals. Doklady Akademii Nauk SSSR, 154:112-115.

Manuscrito A-1290

Recebido em 18 de novembro de 2001

Revisão dos autores em 05 de dezembro de 2001 Revisão accita $\mathrm{em} 07$ de dezembro de 2001 